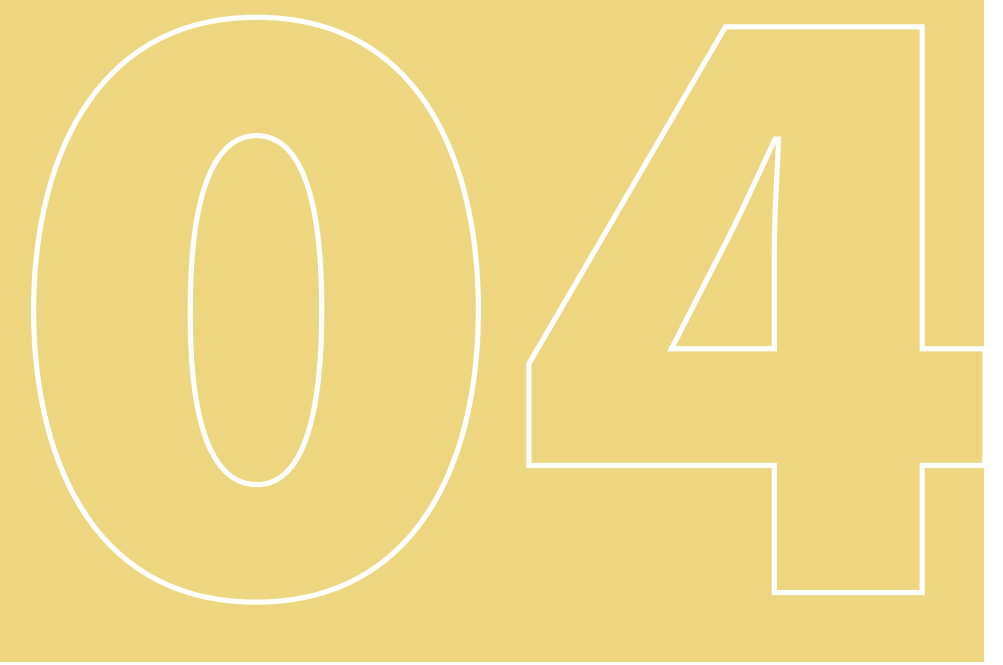

\section{AN OPEN LETTER FROM AN AFRICAN WOMEN SCIENTIST TO RESEARCH ETHICS COMMITTEES}

Una carta abierta de una mujer científica africana a los comités de ética de la investigación

\section{ESTHER DEGUENON}

\section{Research Unit in Applied Microbiology}

and Pharmacology of natural substances,

Polytechnic School of Abomey-Calavi

University of Abomey-Calavi

\section{ABSTRACT}

With inspiring backgrounds, challenges, rich and diverse experiences, African women in science have proven that gender does not matter as long as you have the will and passion. But how many of these women today are recognised for their daily work? From the difficulty of evolving in a male-dominated environment to the challenges of entering a new field, many are the challenges African women face in finding their place in science. African women scientists face the hardship of being a female scientist every day and of being considered the weaker sex. It would be very useful to strengthen the networks of women scientists by facilitating access to information for women scientists and to get them to support each other and, specially, to the younger ones who want to pursue a career in science. African women scientists deserve to be protected in their scientific activities by applicable and binding texts. This is a letter read by its author to members of the Aragón Research Ethics Committee and of the National Ethics Committees of Benin, Guinea Bissau, Guinea Conakry, Mali and Senegal during the opening of the University of Zaragoza-led 2nd International Congress on the Harmonisation of Gender Mainstreaming in West Africa.

\section{Keywords}

Female scientist, challenges, gender equality, female solidarity, ethics. 


\section{RESUMEN}

Con antecedentes inspiradores, desafíos, experiencias ricas y diversas, las mujeres científicas africanas han demostrado que el género no importa siempre que tengas la voluntad y la pasión. Pero ¿cuántas de estas mujeres son reconocidas en su trabajo diario? Desde la dificultad de evolucionar en un entorno dominado por los hombres hasta los desafíos de adentrarse en un campo nuevo, son muchos los desafíos que las mujeres africanas deben afrontar para encontrar su lugar en la ciencia. Las científicas africanas se enfrentan todos los días a las dificultades de ser científicas, y de ser consideradas el sexo más débil. Sería muy útil fortalecer las redes de mujeres científicas facilitando su acceso a la información y promoviendo que se apoyen entre sí y a las más jóvenes que quieran seguir una carrera científica. Las científicas africanas merecen protección en sus actividades científicas mediante textos aplicables y vinculantes. La autora leyó esta carta a los integrantes del Comité de Ética de la Investigación de Aragón y de los Comités Éticos Nacionales de Benín, Guinea Bissau, Guinea Conakry, Malí y Senegal en la apertura del 2. International Congress on the Harmonisation of Gender Mainstreaming in West Africa, liderado por la Universidad de Zaragoza.

\section{Palabras clave}

Científica, desafíos, igualdad de género, solidaridad femenina, ética.

The gender of a noun means that the masculine or feminine does not refer to the nature of things. Let us take a simple example. The chair is no more feminine than the armchair is masculine, and while in French the sun is masculine (as opposed to the moon, which is feminine), the opposite is true in German. In short, gender is a social convention. Gender, a common term in grammar, underlines the constructed and mobile character in time and space of what is called sex elsewhere. This concept is useful for thinking about the formation of social categories. This word is used so frequently today that it has become a language tic among young people to punctuate a sentence. It has spread to all spheres, including of course science. To understand the issue of gender in science, we must first define the concept because, despite its success in various stages, gender is often misunderstood.

Our struggle today is to better understand the inequalities and discrimination that affect women in science in order to better combat them. Recognising and valuing the efforts of the African woman scientist is today a primordial task to achieve in order to effectively accompany the development of Africa. Indeed, women scientists have always tried to make their mark in science. It should be remembered that science in sub-Saharan Africa 
has always been a highly masculinised field and, for this reason, the opportunities given to men are often greater than those given to women. Social representations of the feminine and the masculine differ from one region to another in sub-Saharan Africa, but all come together to accept that women are inferior to men.

Several realities have always constituted bullying factors for the young African woman scientist. I will put all these factors in one package, and I will call it: harassment. I will not focus here on sexual harassment, which is certainly what everyone has been thinking about directly. I can say without a doubt and with conviction that some forms of harassment are sometimes more pervasive and degrading than sexual harassment. I would like to dwell on emotional blackmail, denigration, devaluation of efforts made, and all the corollaries. How many women in sub-Saharan Africa are persecuted on a daily basis, especially by their male colleagues, without being able to say so openly? Sometimes it is impossible to retaliate in order to keep a job or not be noticed or avoid being tagged. How many women in science and in sub-Saharan Africa have been prevented from gaining a distinction, a better position, a rank just because they are women? For many young scientists, it is difficult if not impossible to enjoy moral satisfaction for a job well done because self-doubt is already instilled. How many young scientists, because they have refused to conform to the rules of male colleagues, have been called degrading names and insults?

The number of women scientists who are victims of various abuses is large but this fact is not mentioned. Sometimes, some of them have to accept responsibility for what they are subjected to. I would say that these abuses are primarily due to the fact that women are the weaker sex and that in sub-Saharan culture women are not allowed to take offence at the behaviour of men, who are considered the stronger sex. We hope that change will also begin at the level of the family unit to value women, show them their abilities, and instil self-confidence in them. And here again, many actions could be carried out with the support of the research ethics committees.

How many careers, how many lives, how many homes have been shattered because the woman or young woman suffering the outrages was unable to defend herself because she had no support? Once again, the number is great. Gender equality is not yet a reality in sub-Saharan Africa in all areas of daily life. This is a fundamental right and an integral part of development and social well-being.

Eliminating all forms of gender inequality at national and regional levels through a series of policies, objectives and actions derived from regional, international, continental and legally binding instruments, must be the daily struggle for every African scientist with the accompaniment and support of 
research ethics committees. A struggle for the recognition and valorisation of women's efforts in science. A struggle that is oh so difficult.

There are so many injustices passed over in silence towards the committed scientist and for that reason so many grievances that she would certainly like to have the opportunity to formulate.

We hope that she will be given the opportunity to protect herself by means of imposed texts. We, therefore, encourage all young scientists to continue to give priority to work well done by refusing to take the easy way out in order to impose respect for their male colleagues.

We hope one day to see female solidarity go beyond its known limits and, through its commitment, force positive change.

To finish my letter, I would like to thank all the older women scientists who are fighting so that the younger generation does not suffer the abuses they have had to face. You are our Amazons.'

Continue to show us the way as you know how to do so well.
1. The Dahomey Amazons (also known as The Mino) were an all-female military regiment of the pre-colonial African Kingdom of Dahomey (present-day Benin). 